\title{
Job Stress, Compensation, Job Dissatisfaction and Turnover Intention
}

\author{
Kusni Ingsih ${ }^{1, *}$, Ana Kadarningsih ${ }^{2}$, Nova Rijati ${ }^{3}$ \\ ${ }^{1,2,3}$ University of Dian Nuswantoro, Semarang, Indonesia \\ kusni.ingsih@dsn.dinus.ac.id
}

\begin{abstract}
Turnover refers to employees who intend to leave their jobs due to decreased employee numbers and the associated costs of recruiting and recruiting new employees. Job stress, compensation, and job satisfaction are all factors that can contribute to an employee quitting his or her job. This study enrolled all employees at PT Citra Mandiri Multi Finance. The respondents were gathered through an incidental sampling method. Multiple linear regression was used for analysis in this study. The findings indicate that job stress increases turnover intention, compensation decreases turnover intention, and dissatisfaction increases turnover intention. The implication of this research is the critical importance of businesses paying attention to the factors that influence turnover intention because the higher a company's turnover intention, the higher the company's human resource costs.
\end{abstract}

Keywords: job stress, compensation, dissatisfaction, and turnover intentions

\section{INTRODUCTION}

PT Citra Mandiri Multi Finance is an Indonesian leasing company that claims to be a market leader in the highly competitive leasing industry. The success of this business undoubtedly has something to do with its human resources. PT Citra Mandiri Multi Finance has expanded to nearly every province in Indonesia, including Semarang. PT Citra Mandiri Multi Finance, as a representative office for the two-wheeled vehicle segment, must, of course, have high-performing employees to maintain and grow the company's success. However, according to 2020 data from the company, employee turnover is extremely high, ranging between $10 \%$ and $33 \%$ per month. This demonstrates that the company has a problem, as numerous employees leave and rejoin the company. The desire to leave has developed into an intriguing subject that has attracted the attention of numerous researchers in the field of human resources. If an employee expresses a desire to go, this indicates a conflict between the employee and the company. Two factors can influence the desire to leave: organizational and individual characteristics. Salary considerations, heavy work, inflexible work hours, and an unsupportive work environment are all examples of organizational factors that can contribute to a desire to leave. While individual characteristics such as family and work conflicts can contribute to the desire to leave. Turnover is the behaviour of employees closely related to their desire to leave their jobs, resulting in declining employee continuity and high costs associated with recruiting and training new employees. Job stressors, compensation, and a lack of job satisfaction are all factors that can contribute to an employee's desire to quit. Earlier research has yielded various findings regarding the factors that influence turnover intention. According to research [1], [2], [3], [4], [5], and [6], work stress has a beneficial effect on intention to leave. While work stress does not have a significant effect on the intention to leave, as demonstrated by [7], [8], and [9]. Along with job stress, compensation is another factor that influences turnover intention. Compensation has a negative effect on turnover intention, according to research from [5] and [10], [11], [12], and [13]. However, [14] discovered the opposite, namely that compensation did not affect turnover intention. Apart from job stress and compensation, another factor is job satisfaction. Job satisfaction has an effect on turnover intention, according to research from [5], [13], and [15], [16]. This contradicts the findings of [17], [18], who demonstrate the opposite, namely that job satisfaction does not affect turnover intention. This research is worth reviewing based on the arguments and the variations in research findings. As a result, the research question becomes whether work stress, compensation, and job satisfaction all influence turnover intention. 


\section{LITERATURE REVIEW AND HYPOTHESES DEVELOPMENT}

Variable concept and hypothesis development turnover intention is how an employee wishes to leave the company. Numerous factors contribute to turnover intention. One of the reasons is to improve one's job prospects. The turnover intention must be addressed as a phenomenon and human behavior critical to the organization's life, both personally and socially. The employee's intention to leave will significantly impact both the company and the individual.

Stress is a person's adaptive response to stimuli that place an individual under excessive psychological or physical demands. On the other hand, stress can be an adaptive response that is influenced by individual differences. It results from any action, circumstance, or event that places additional demands on a person. Job stress is also a tension condition that throws the body's physics and psychology out of balance. It can affect an employee's emotions, thought processes, and physical state. If a person is overly stressed, it can jeopardize their ability to deal with the environment. Compensation is a form of remuneration that employees receive based on their performance and is intended to improve employee welfare and productivity. Compensation can be quantified by the number of wages/salaries paid to employees. Six factors determine compensation:

1. Demand and supply of employee skills.

2. Trade union organization.

3. The ability of the company to pay.

4. Company productivity.

5. Cost of living.

6. Government regulations.

Dissatisfaction is a critical factor in a business; it is an employee's attitude toward fulfilling certain desires and needs through work or work activities because job satisfaction is determined by how the company treats its employees.

Job Stress and Intention to Leave. Employee stress has a significant negative impact on a business, as employee stress can result in relatively easy losses for the business. Work stress is a symptom that can affect an individual's performance at work. The source of stress that impairs a person's ability to function optimally or causes a person to become ill does not come from a single source of stress but a combination of sources. Humans spend the majority of their time working. As a result, the work environment has a significant impact on the health of those who work. Stressors at work contribute significantly to a worker's inability to function or become ill. As a result, if employees are stressed at work, they desire to leave the company. This means that the more stress employees face, the greater their intention to leave, and vice versa, the fewer stress employees face, the lower their intention to leave. This argument is consistent with the findings of [1], [2], [3], [4], [5], and [6], which indicate that work stress affects turnover intention. According to the description, the study's first hypothesis is H1. Work stress has a beneficial effect on turnover intention.

Compensation and Intention to Turnover. Compensation plays a significant role in determining how and why individuals choose to work for one organization over another. Compensation is critical for the individual employee. Compensation is a reflection of the employee's work's value. Employee stability is one of the compensation system's objectives. Employee stability can be easily achieved through compensation provision if the employee believes that the compensation provided by the company was determined based on fairness, feasibility, and external consistency. The more appealing the compensation factor, the less likely an employee will leave the organization.

On the other hand, the lower the level of compensation received, the more likely employees will leave the organization and seek employment elsewhere. This is consistent with the research findings of [5], [10], [11], [12], and [13], which demonstrate that compensation affects turnover intention. As a result, the second hypothesis of this study is as follows: $\mathrm{H} 2$. Compensation has a detrimental effect on turnover intention.

Dissatisfaction and Intention to Leave. Dissatisfaction arises from growing globalization in the organization's life, increasing business competition, the shorter product and service life cycles offered, and growing consumer preferences for the products and services offered. Many businesses are looking for new technological breakthroughs to prepare for all of this. Disappointment can act as a catalyst and interpreter. Employees who cannot track the company's progress in terms of information technology use will develop a desire to leave. Turnover intention is the result (outcome) demonstrated by employees in the form of behavior resulting from dissatisfaction with their work. However, if an employee can master the material/technology provided by the company, the employee will be better equipped to perform their duties and expand their minds. [5], [13], and [15], [16] demonstrate that job satisfaction affects the intention to leave. As a result, the third hypothesis in this study is H3. Dissatisfaction hurts the intention to leave.

\section{RESEARCH METHOD}

The study is quantitative and is based on primary data. Primary data are gathered through the distribution of questionnaires that respondents must complete. The population of this study was comprised of all employees at PT Citra Mandiri Multi Finance, and the sample size was 81 respondents. Random sampling is 
used as the sampling technique. Multiple linear regressions will be used to analyze the data. Validity and reliability tests, in addition to classical assumption tests, were used to conduct the tests. This is done to obtain the desired results.

\section{RESULTS AND DISCUSSION}

Female respondents made up $62.86 \%$, while male respondents made up $37.14 \%$. Female respondents outnumber male respondents, which is unsurprising given that female employees are undeniably more detailed, concentrated, and neat in executing the target achievement strategy. Additionally, female employees are known for their ability to make sound judgments. Employees aged 31-35 years dominate the workforce with $34.16 \%$. This is because employees at that age typically have a career path and sufficient work experience. Employees of that age generally are already at the executive level, and some have been entrusted with the responsibility of leading a division. According to the respondents' education level, most have a diploma, accounting for $56.32 \%$. The diploma curriculum places a high premium on practice, ensuring that students gain valuable work experience. Validity and reliability tests indicate that the data in this study are both valid and reliable. According to table 3, the Adjusted R Square value of 0.549 indicates that the variables of work stress, compensation, and job dissatisfaction can explain $54.9 \%$ of the variance in turnover intention. In comparison, the remaining $45.1 \%$ is explained by variables not examined in the research. Job Stress and Intention to Leave. The findings indicated that job stress had a beneficial effect on turnover intention. The result is consistent with the findings of [1], [2], [3], [4], [5], and [6], which indicate that job stress affects turnover intention. This relationship demonstrates that job stress is a significant factor in employees' desire to leave the company where they currently work. Thus, the greater the job stress employees endure, the greater the likelihood of turnover. The finding contradicts previous research [7], [8], and [9], which indicate that job stress does not affect employee turnover intention.
Compensation and Intention to Turnover. Balance has a detrimental effect on turnover intention, as demonstrated by the findings. This means that the higher the compensation, the less likely an employee is to leave. Salary commensurate with the service period should be increased; this is consistent with the tenure theory, which states that the longer the tenure, the better the compensation received. It is hoped that the company's compensation system should be evaluated based on the employee's tenure. The provision of attractive bonuses still needs to be improved in the hope that employees will contribute ideas and develop work skills that are commensurate with their abilities, thereby decreasing their interest in looking for alternative employment and leaving the company. This demonstrates that compensation plays a significant role in lowering turnover intentions. Employees' perceptions of the salary offered by PT Citra Mandiri Multi Finance are influenced by its suitability. Employees are satisfied when their compensation is commensurate with their work; however, if their salary is not commensurate with their workload, they will leave PT Citra Mandiri Multi Finance. The findings of research on the effect of compensation on employee turnover intention are corroborated by [5], [10], [11], and [13], who asserts that settlement has a negative effect on employee turnover intention. This finding, however, contradicts [14], which states that compensation does not affect turnover intention. Job Dissatisfaction and Intention to Leave. The findings indicated that job dissatisfaction positively affects the intention to leave. Leaving a company begins with increasing employee dissatisfaction with their jobs. This heightens the desire to flee. Employees who are dissatisfied with their jobs frequently consider going, searching for alternative job opportunities, evaluating the possibility of obtaining alternative job opportunities, and wishing to leave to find a more satisfying job. [5], [13], and [15], [16] conducted research demonstrating that job dissatisfaction has a negative effect on turnover intention. On the other hand, these findings contradict those of [17], [18], who demonstrate that job satisfaction does not affect turnover intention.

\begin{tabular}{clcccc}
\hline Num. & Variable & $\alpha$ & $\begin{array}{c}\text { Cronbach's } \\
\text { Alpha }\end{array}$ & $\begin{array}{c}\text { Standard } \\
\alpha\end{array}$ & Annotation \\
\hline 1. & Job Stres & 0.05 & 0.721 & 0.70 & Reliable \\
2. & Dissatisfaction & 0.05 & 0.961 & 0.70 & Reliable \\
3. & Compensation & 0.05 & 0.798 & 0.70 & Reliable \\
4. & Turnover Intention & 0.05 & 0.822 & 0.70 & Reliable
\end{tabular}

Table 1. Reliability and Validity Test 


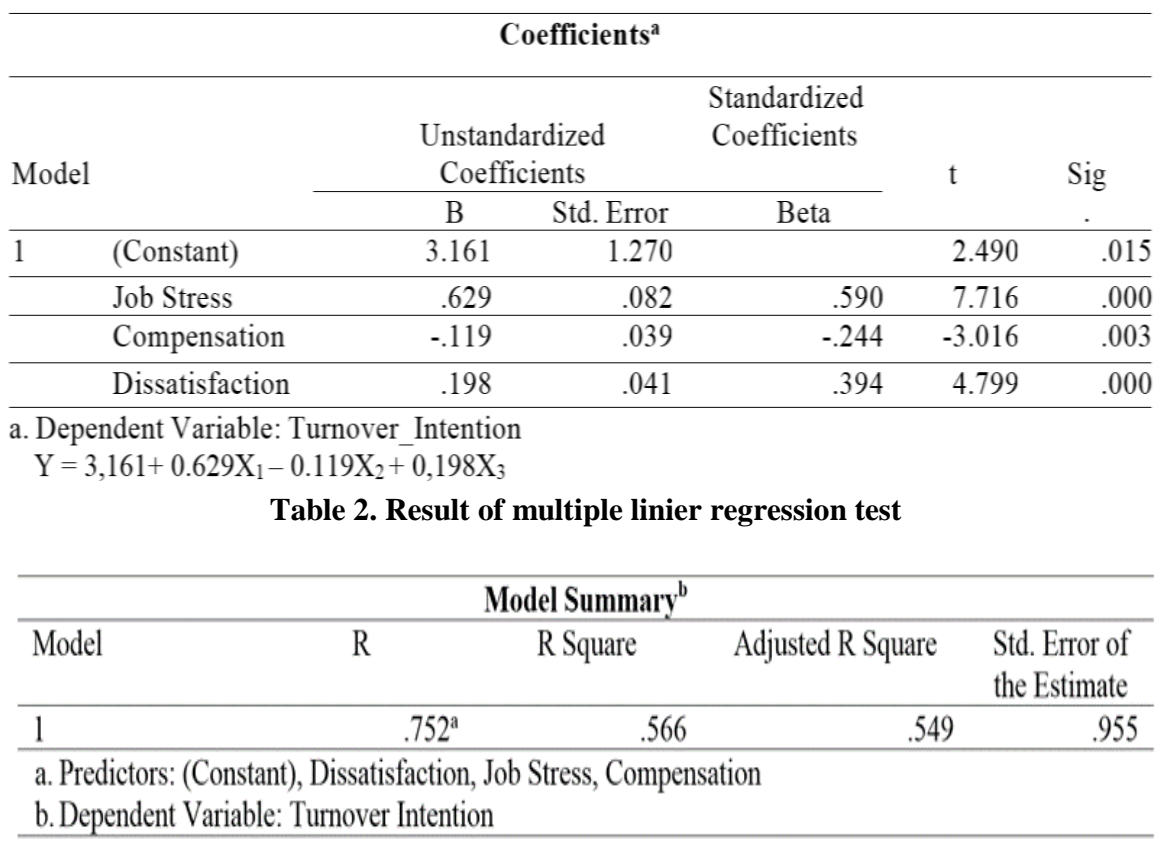

Table 3. Result of determination coefficient test

\section{CONCLUSION AND RECOMMENDATION}

The findings, analysis, and discussion indicate that work stress positively affects turnover intention, compensation harms turnover intention, and dissatisfaction positively impacts turnover intention. The research implication is that businesses must pay attention to the factors that influence turnover intention. The higher a company's turnover intention, the higher the costs associated with human resources.

\section{REFERENCES}

1. Lu, Yong. The Relationship Between Job Satisfaction, Work Stress, Work-Family Conflict an Turnover Intention among Physicians in Guangdong, China: A Cross-Sectional Study. BMJ Open, 7, 1-12 (2017).

2. Hakim, A.D. Sudarmiatin, S. The Effect of Work Stress on Turnover Intention with Work Satisfaction and Commitment as Intervening Variable (Study at PT Infomedia Solusi Humanika in Malang). European Journal of Business and Management, 10(1), 85-94 (2018).

3. Zahra, S. Khan, M. Imran, M. Aman, Q. Ali, R. The Relationship Between Job Stress and Turnover Intention in the Pesticide Sector of Pakistan: An Amployee Behaviour Perspective. Journal of Management Issues in Healthcare System, 4, 1-12 (2018).

4. Akbar, M. R and Mayliza, R. Pengaruh stres kerja dan kesempatan promosi terhadap turnover intention pada
CV. Anisa Fadly Kabupaten Padang Pariaman. OSF Preprints, 1-17 (2019).

5. Ramlah, Sri. Ahmad Sudiro, Himmiyatul Amanah Jiwa Juwita. The Influence of Compensation and Job Stress on Turnover Intention Through Mediation of Job Satisfaction. International Journal of Research in Business and Social Science, 10(4), 117-127 (2021).

6. Wibowo Akbar, Margono Setiawan, Agung Yuniarinto. The Effect of Workloads on Turnover Intention With Work Stress as Mediation and Social Support as Moderated Variables. Journal of Applied Management, 19(2), 404-412 (2021).

7. Tongchaiprasit, P. Ariyabuddhiphongs. Creativity and Turnover Intention Among Hotel Chefs: The Mediating Effects of Job Satisfaction and Job Stress. International Journal of Hospitality Management, 55, 33-40 (2016).

8. Chung, E.K, Jung, Y. Sohn, Y.W. A Moderated Mediation Model of Job Stress, Job Satisfaction and Turnover Intention for Airport Security Screeners. Safety Science, 98, 89-97 (2017).

9. Endang Suswati. The Influence of Work Stress on Turnover Intention: Employee Performance as Mediator in Casual-Dining Restaurant. Journal of Applied Management, 18(2), 391-399 (2020).

10. Ghafoor, S. Ansari, N. Moazzam. The Effect of Financial Compensation and Perceived Career Progression on Employee Turnover Intentions with Self Actualization as A Mediator. Governance and Management Review, 1(2), 67-91 (2017).

11. Silaban, Normariati, Tantri Yanuar Rahmat Syah. The Influence of Compensation and Organizational Commitment on Employees' Turnover Intention. Journal of Business and Management, 20(3), 1-6 (2018). 
12. Laraswani, Rini. Lubis, Risa Kartika. The Effect of Compensation and Work Environment on Turnover Intention at PT. Putra Dolok Mandiri. Journal of Management Science, 3(3), 86-90 (2020).

13. Vizano, Nico Alexander, Ahmad Hidayat Sutawidjaja, Endri. The Effect of Compensation and Career on Turnover Intention: Evidence from Indonesia. Journal of Asian Finance, Economics and Business, 8(1), 471-478 (2021).

14. Choiriyah, Fatimah, Amir, M. The effect of financial compensation and job satisfaction against turnover intention of Muhammadiyah hospital employees Palembang. WMA (2018) 10.4108/eai.20-12018.2282069.

15. Rismiyanti, R.D. Musadieq, M.Al. Aini, E.K. The Effect of Work Satisfaction on Turnover Intention and Its Impact on Employee Performance (Study on Permanent
Employees of PG Kebon Agung Malang). Journal of Business Administration, 61(2), 127-136 (2018).

16. Susanto, et al. The Effect of Task Complexity, Independence and Competence on The Quality of Audit Results with Auditor Integrity as A Moderating Variable. International Journal of Innovation, Creativity and Change, 12(12), 742-755 (2020).

17. Tran, et al. The Impact of Organisational Commitment on the Relationship Between Motivation and Turnover Intention in the Public Sector. International Journal of Innovation, Creativity and Change, 11(12), 1-25 (2020).

18. Dewi, Rintis Sukma. Nurhayati, Mafizatun. The Effect of Career Development on Turnover Intention with Job Satisfaction and Organizational Commitment as Mediators, Study at PT. Control Systems Arena Para Nusa. European Journal of Business and Management Research, 6(4), 11-18 (2021). 